\title{
Patient Satisfaction Level with Health Care Quality at Dental Hospital of Hasanuddin University
}

\author{
Fuad Husain Akbar \\ Department Dental Public Health, Faculty of Dentistry \\ Hasanuddin University \\ Makassar, Indonesia \\ fuadgi2@gmail.com
}

\author{
Burhanuddin Pasiga \\ Department Dental Public Health, Faculty of Dentistry \\ Hasanuddin University \\ Makassar, Indonesia
}

\begin{abstract}
Patient satisfaction that related with quality of service is relation of perceptions of the care received and his expectations before getting the service. Most complaints of patients in a satisfaction survey concerning the presence of officers who are not professional in providing health services. This research is observational with cross sectional study design, which held on April 2016. Sample in this research were 94 patients who received treatment in Oral Surgery, Periodontology, Conservation, and Prosthodontic Department in Dental Hospital of Hasanuddin University. At the confidentiality of the disease, there is 6 people feel very satisfied, 55 people feel satisfied, 32 people feel quite satisfied, and one person was not satisfied. There are 16 people feel very satisfied, 52 people feel satisfied, 25 people feel enough satisfied, and 1 person was not satisfied with dimension empathy. Responsiveness in resolving patient complaints, 14 people feel very satisfied, 53 people feel satisfied, 26 people feel quite satisfied, and one person was not satisfied. Patients want a skilled officer who can provide them with information. They also want health care providers to work as a collaborative team and communicate with each other effectively to provide good quality services. Environment and being comfort in the room and room service are the key for patients statisfaction. Communicatio $n$ is also an essential established between patient and doctor. Conclusion, Patients was satisfied with the health services in dental hospital of Hasanuddin University based on four dimensions studied: assurance, empathy, responsiveness, and physical appearance.
\end{abstract}

Keywords--satisfaction level; quality of health care; dental hospital

\section{INTRODUCTION}

The key of oral health service is depending of the degree of statisfaction of its patients. Patient satisfaction related with quality of service is the ratio between the perceptions of the care received by his expectations before getting the service. If expectations are met, it means the service has provided an exceptional quality and will also lead to high satisfaction. Conversely, if their expectations are not reached, it means that service quality does not meet what is expected [1][2][3].

The hospital declared a success, not only on the completeness of that facilities, but also the attitude and human resource services is an element which significantly influence the services produced and perceived patient.
When these elements are ignored, it will affect the treatment in the future and also affected to patient's loyalty the hospital will lose shunned by many patients and prospective patients. Itself the basis of the hospital is meeting the needs and demands of patients who expect the completion of his health problems at hospitals [4][5].

Dental hospital is health facilities conducting dental and oral health services for individual treatment and recovery services without ignoring the improvement of health care and disease prevention implemented through ambulatory care services and medical action [3].

The results of several surveys show that patient satisfaction many influenced directly by the quality of services provided by hospitals particularly those associated with hospital facilities, the services and resources that work at the hospital. Most complaints of patients in a satisfaction survey concerning the presence of officers who are not professional in providing health services, which are still audible complaint would be the clerk unfriendly and indifferent to patient complaints. The most prominent factor is the quality of service; treatment time is long, long waiting times and outcomes of care were less than satisfactory [4][7][8].

Problem Statement in this research is measure the level of patient satisfaction with health services in dental hospital of Hasanuddin University. The purpose of this study was to determine the level of patient satisfaction with health services in hospitals dental hospital of Hasanuddin University. The benefits of this research is to provide feedback to students and the professional level of management in dental hospital of Hasanuddin University with terms of management evaluation has been done, especially in the provision of health care to patients.

\section{METHOD}

This type of research is observational with cross sectional study design. This research was conducted in dental hospital of Hasanuddin University, and held on april 2016. The population in this research were patients who received hospital treatment in dental hospital of Hasanuddin 
University. Esepcially in choosen department such as oral surgery, periodontology, conservation, and prosthodontic department we were collected 94 sampels, which obtained each department in follow 30 sampels from oral surgery department, 27 samples from periodontology, 26 samples from conservation department and 11 samples from prosthodontic department.

Inclusion criteria patients who are at the oral surgery, periodontology, conservation and prosthodonsi, willing to fill out a questionnaire, exclusion criteria patients who were previously, patients who are not at the oral surgery, periodontology, conservation and prosthodontic.

Patient satisfaction is feeling statisfied or disappointed someone who emerged after comparing the performance think of the performance is expected. The quality of hospital services in the measure of four (4) dimensions of quality: Tangibles (physical appearance), responsiveness (responsiveness), assurance (assurance), empathy (empathy). The questionnaire translated into bahasa Indonesia and assessed based on satisfaction questions within a 5-point Likert scale [9][10].

\section{RESULTS}

Measuring the level of satisfaction was conducted using questionnaires dental and oral health services to the distribution of the sample according to gender, age, education, employment, funding source, the source of clinical information, the reason for the visit, and the frequency of visits. The questionnaire translated in Bahasa Indonesia. Questionnaires in dental and oral health services consists of 18 questions with four dimensions, they are assurance, empathy, responsiveness, and physical appearance. The results of the sample answers are accumulated and converted into a category of overall satisfaction. All the results are collected and further research is done processing and analyzed using SPSS. Results of the study appear in the distribution table as follows.

Table I. Number of samples in this study was $94(100 \%)$ which consisted of 29 men (30.6\%) and 65 women (69.1\%). The sample had a job as a student sample with the highest frequency, is $44(46.8 \%)$. By level of education, most samples are colleges with the number of 53 people $(56.3 \%)$. In addition, samples of which came on dental care services at dental hospital of Hasanuddin University.

Based on data obtained, clinical information resource that most from friend with a number of 52 people $(55.3 \%)$. In addition, the reason for the visit with the largest sample that is on the revocation by the number of 30 people $(31.9 \%)$. When viewed from the frequency of dental care visits, is the highest number of visits on the first visit by the number of 49 people (52.1\%).

Table II. shows the level of patient satisfaction with dental health services in dental hospital of Hasanuddin University in terms of dimensions of security services. At the confidentiality of the disease the patient is awake for 6 people feel very satisfied, 55 people feel satisfied, 32 people feel quite satisfied, and 1 person was not satisfied. Explanation of working procedures or actions were 9 people who feel very satisfied, 54 people feel satisfied, 30 people feel quite satisfied, and 1 person who was not satisfied. Skills and knowledge of young doctors handle patient complaints were 9 people feel very satisfied, 57 people feel satisfied, 27 people feel quite satisfied, and one person was not satisfied. The explanation is easy to understand the results of as many as 13 people are very satisfied, satisfied feel 56 people, 25 people feel quite satisfied.

Table III. shows the level of patient satisfaction with dental health services in dental hospital of Hasanuddin University terms of service dimension of empathy for Service delivery regardless of the social status of 20 people feel very satisfied, and Clarity of information and attitude of the clerk 7 people are not satisfied.

Table IV. shows the level of patient satisfaction with dental health care in dental hospital of Hasanuddin University terms of service dimension of responsiveness of young doctors in resolving complaints father / mother / brother as many as 14 people feel very satisfied, and Speed of the administration in providing services as many 4 people are not satisfied.

Table V. responses questions about service dimension physical appearance the dental hospital of Hasanuddin University to the will the doctor as many as 28 people feel very satisfied, and cleanliness of equipment to check the patient's teeth as much as 5 people are not satisfied.

Table VI. respons questions about the percentage distribution of the sample based on the dimensions of the satisfaction level of health services in hospitals dental health faculty of dentistry, university of hasanuddin the empathy dimension as many as 68 people satisfied and Physical appearance dimension 26 people dissatisfied 
TABLE I. DISTRIBUTION OF THE SAMPLE ACCORDING TO GENDER, AGE, EDUCATION, OCCUPATION, SOURCE OF CLINICAL INFORMATION, THE REASON FOR THE VISIT, AND THE FREQUENCY OF VISITS.

\begin{tabular}{|c|c|c|}
\hline Variable & $\begin{array}{c}\text { Frequency } \\
\text { (n) }\end{array}$ & Percent (\%) \\
\hline \multicolumn{3}{|l|}{ Gender } \\
\hline Man & 29 & 30.9 \\
\hline Women & 65 & 69.1 \\
\hline \multicolumn{3}{|l|}{ Last Education } \\
\hline D3 & 1 & 1.1 \\
\hline University & 53 & 56.3 \\
\hline Primary School & 11 & 11.7 \\
\hline From High School & 14 & 14.9 \\
\hline Junior High School & 13 & 13.8 \\
\hline No School & 1 & 1.1 \\
\hline Not Completed Primary School & 1 & 1.1 \\
\hline \multicolumn{3}{|l|}{ Job } \\
\hline Tutor & 1 & 1.1 \\
\hline Housewife & 14 & 14.9 \\
\hline College Student & 44 & 46.8 \\
\hline Trader & 8 & 8.5 \\
\hline Private Employees & 5 & 5.3 \\
\hline Student & 4 & 4.3 \\
\hline Nurse & 1 & 1.1 \\
\hline Not Working & 11 & 11.7 \\
\hline Entrepreneur & 6 & 6.3 \\
\hline \multicolumn{3}{|l|}{ Clinic Information } \\
\hline From Friend & 52 & 55.3 \\
\hline From College Student & 32 & 34 \\
\hline See in Name Board & 10 & 10.7 \\
\hline \multicolumn{3}{|l|}{ Reason For Visit } \\
\hline Scaling & 27 & 28.7 \\
\hline Protesa & 11 & 11.7 \\
\hline Extraction & 30 & 31.9 \\
\hline Tooth Filling & 26 & 27.7 \\
\hline \multicolumn{3}{|l|}{ Number of Visits to Hospital } \\
\hline Visit 1 & 49 & 52.1 \\
\hline Visit 2 & 19 & 20.2 \\
\hline Visit 3 & 10 & 10.7 \\
\hline Visit 4 & 2 & 2.1 \\
\hline Visit 5 & 2 & 2.1 \\
\hline Visit 6 & 2 & 2.1 \\
\hline Visit 7 & 1 & 1.1 \\
\hline Visit 8 & 4 & 4.3 \\
\hline Visit 10 & 5 & 5.3 \\
\hline
\end{tabular}

TABLE II. DISTRIBUTION RATE OF PATIENT SATISFACTION WITH HEALTH SERVICES IN DENTAL HOSPITAL, FACULTY OF DENTISTRY, UNIVERSITY OF HASANUDDIN, BASED ON DIMENSION OF SERVICE GUARANTEES.

\begin{tabular}{|c|c|c|c|c|c|c|}
\hline \multirow[b]{2}{*}{ Question Satisfaction } & \multicolumn{5}{|c|}{ Asssessment Scores } & \multirow[b]{2}{*}{$\begin{array}{c}\mathbf{n} \\
\%\end{array}$} \\
\hline & $\begin{array}{l}\text { Very Dissatisfied } \\
n(\%)\end{array}$ & $\begin{array}{c}\text { Not } \\
\text { Satisfied } n \\
(\%)\end{array}$ & $\begin{array}{c}\text { Quite } \\
\text { Satisfied } \\
n(\%)\end{array}$ & $\begin{array}{l}\text { Satisfied } \\
n(\%)\end{array}$ & $\begin{array}{c}\text { Very } \\
\text { Satisfied } \\
n(\%)\end{array}$ & \\
\hline $\begin{array}{l}\text { 1). Do Confidentiality regarding the disease father / mother / } \\
\text { brother awake }\end{array}$ & $\begin{array}{c}0 \\
(0.0) \\
\end{array}$ & $\begin{array}{c}1 \\
(1.1) \\
\end{array}$ & $\begin{array}{c}32 \\
(34.0) \\
\end{array}$ & $\begin{array}{c}55 \\
(58.5) \\
\end{array}$ & $\begin{array}{c}6 \\
(6.4) \\
\end{array}$ & $\begin{array}{c}94 \\
100 \% \\
\end{array}$ \\
\hline 2).How to explain the work procedures / actions & $\begin{array}{c}0 \\
(0.0) \\
\end{array}$ & $\begin{array}{c}1 \\
(1.1) \\
\end{array}$ & $\begin{array}{c}30 \\
(31.9) \\
\end{array}$ & $\begin{array}{c}54 \\
(57.4) \\
\end{array}$ & $\begin{array}{c}9 \\
(9.6) \\
\end{array}$ & $\begin{array}{c}94 \\
100 \% \\
\end{array}$ \\
\hline 3). What about the ability and knowledge of young doctors & $\begin{array}{c}0 \\
(0.0)\end{array}$ & $\begin{array}{c}1 \\
(1.1) \\
\end{array}$ & $\begin{array}{c}27 \\
(28.7) \\
\end{array}$ & $\begin{array}{c}57 \\
(60.6) \\
\end{array}$ & $\begin{array}{c}9 \\
(9.6) \\
\end{array}$ & $\begin{array}{c}94 \\
100 \% \\
\end{array}$ \\
\hline $\begin{array}{l}\text { 4). What is the explanation examination by young doctors can be } \\
\text { easily understood }\end{array}$ & $\begin{array}{c}0 \\
(0.0)\end{array}$ & $\begin{array}{c}0 \\
(0.0)\end{array}$ & $\begin{array}{c}25 \\
(26.6)\end{array}$ & $\begin{array}{c}56 \\
(59.6)\end{array}$ & $\begin{array}{c}13 \\
(13.8)\end{array}$ & $\begin{array}{c}94 \\
100 \%\end{array}$ \\
\hline
\end{tabular}


TABLE III. DISTRIBUTION RATE OF PATIENT SATISFACTION WITH HEALTH SERVICES IN HOSPITALS DENTAL FACULTY OF DENTISTRY, UNIVERSITY OF HASANUDDIN BASED SERVICE DIMENSION OF EMPATHY

\begin{tabular}{|c|c|c|c|c|c|c|}
\hline \multirow[b]{2}{*}{ Question Satisfaction } & \multicolumn{5}{|c|}{ Assessment Score } & \multirow[b]{2}{*}{$\begin{array}{c}\mathbf{n} \\
\%\end{array}$} \\
\hline & $\begin{array}{c}\text { Very } \\
\text { Dissatisfied } \\
n(\%)\end{array}$ & $\begin{array}{c}\text { Not } \\
\text { Satisfied } \\
n(\%)\end{array}$ & $\begin{array}{c}\text { Quite } \\
\text { Satisfied } \\
n(\%)\end{array}$ & $\begin{array}{l}\text { Satisfied } \\
n(\%)\end{array}$ & $\begin{array}{c}\text { Very } \\
\text { Satisfied } \\
n(\%)\end{array}$ & \\
\hline $\begin{array}{l}\text { 1). How Attitude seriousness dentists in examining and handling } \\
\text { complaints father / mother / brother (ex: listening and caring) }\end{array}$ & $\begin{array}{c}0 \\
(0.0) \\
\end{array}$ & $\begin{array}{c}1 \\
(1.1) \\
\end{array}$ & $\begin{array}{c}25 \\
(26.6) \\
\end{array}$ & $\begin{array}{c}52 \\
(55.3)\end{array}$ & $\begin{array}{c}16 \\
(17.0)\end{array}$ & $\begin{array}{c}94 \\
100 \% \\
\end{array}$ \\
\hline 2). Is the service delivery regardless of social status & $\begin{array}{c}0 \\
(0.0)\end{array}$ & $\begin{array}{c}0 \\
(0.0)\end{array}$ & $\begin{array}{c}20 \\
(21.3)\end{array}$ & $\begin{array}{c}54 \\
(57.4) \\
\end{array}$ & $\begin{array}{c}20 \\
(21.3)\end{array}$ & $\begin{array}{c}94 \\
100 \% \\
\end{array}$ \\
\hline 3). How Attention dentists in providing services & $\begin{array}{c}0 \\
(0.0) \\
\end{array}$ & $\begin{array}{c}1 \\
(1.1)\end{array}$ & $\begin{array}{c}24 \\
(25.5) \\
\end{array}$ & $\begin{array}{c}52 \\
(55.3) \\
\end{array}$ & $\begin{array}{c}17 \\
(18.1)\end{array}$ & $\begin{array}{c}94 \\
100 \% \\
\end{array}$ \\
\hline 4). How Clarity provides information about the disease & $\begin{array}{c}0 \\
(0.0) \\
\end{array}$ & $\begin{array}{c}2 \\
(2.1) \\
\end{array}$ & $\begin{array}{c}29 \\
(30.9)\end{array}$ & $\begin{array}{c}55 \\
(58.5) \\
\end{array}$ & $\begin{array}{c}8 \\
(8.5) \\
\end{array}$ & $\begin{array}{c}94 \\
100 \% \\
\end{array}$ \\
\hline 5). How Clarity provides instruction before treatment & $\begin{array}{c}0 \\
(0.0)\end{array}$ & $\begin{array}{c}1 \\
(1.1)\end{array}$ & $\begin{array}{c}29 \\
(30.9)\end{array}$ & $\begin{array}{c}57 \\
(60.6)\end{array}$ & $\begin{array}{c}7 \\
(7.4) \\
\end{array}$ & $\begin{array}{c}94 \\
100 \% \\
\end{array}$ \\
\hline 6). How Clarity of information and attitudes administrative officer & $\begin{array}{c}0 \\
(0.0)\end{array}$ & $\begin{array}{c}7 \\
(7.5)\end{array}$ & $\begin{array}{c}33 \\
(35.1)\end{array}$ & $\begin{array}{c}46 \\
(48.9)\end{array}$ & $\begin{array}{c}8 \\
(8.5)\end{array}$ & $\begin{array}{c}94 \\
100 \%\end{array}$ \\
\hline
\end{tabular}

TABLE IV. DISTRIBUTION RATE OF PATIENT SATISFACTION WITH HEALTH CARE TREATMENT IN HOSPITAL DENTAL FACULTY OF DENTISTRY, UNIVERSITY OF HASANUDDIN BASED ON THE DIMENSIONS OF SERVICE RESPONSIVENESS.

\begin{tabular}{|c|c|c|c|c|c|c|}
\hline \multirow[b]{2}{*}{ Question Satisfaction } & \multicolumn{5}{|c|}{ Assessment Scores } & \multirow[b]{2}{*}{$\begin{array}{l}\mathbf{n} \\
\%\end{array}$} \\
\hline & $\begin{array}{l}\text { Very Dissatisfied } \\
n(\%)\end{array}$ & $\begin{array}{l}\text { Not Satisfied } \\
\quad n(\%)\end{array}$ & $\begin{array}{c}\text { Quite } \\
\text { Satisfied } \\
n(\%)\end{array}$ & $\begin{array}{c}\text { Satisfied } \\
n(\%)\end{array}$ & $\begin{array}{l}\text { Very Satisfied } \\
\quad n(\%)\end{array}$ & \\
\hline 1). How young doctors Speed in handling complaints & $\begin{array}{c}0 \\
(0.0)\end{array}$ & $\begin{array}{c}5 \\
(5.3)\end{array}$ & $\begin{array}{c}24 \\
(25.5)\end{array}$ & $\begin{array}{c}53 \\
(56.4)\end{array}$ & $\begin{array}{c}12 \\
(12.8)\end{array}$ & $\begin{array}{c}94 \\
100 \%\end{array}$ \\
\hline $\begin{array}{l}\text { 2). How Responsiveness of young doctors in resolving } \\
\text { complaints father / mother / brother }\end{array}$ & $\begin{array}{c}0 \\
(0.0)\end{array}$ & $\begin{array}{c}1 \\
(1.1)\end{array}$ & $\begin{array}{c}26 \\
(27.7)\end{array}$ & $\begin{array}{c}53 \\
(56.4)\end{array}$ & $\begin{array}{c}14 \\
(14.8)\end{array}$ & $\begin{array}{c}94 \\
100 \%\end{array}$ \\
\hline $\begin{array}{l}\text { 3). How to Speed administration section (registration area) in } \\
\text { providing services. }\end{array}$ & $\begin{array}{c}0 \\
(0.0)\end{array}$ & $\begin{array}{c}4 \\
(4.3) \\
\end{array}$ & $\begin{array}{c}38 \\
(40.4)\end{array}$ & $\begin{array}{c}39 \\
(41.5)\end{array}$ & $\begin{array}{c}13 \\
(13.8)\end{array}$ & $\begin{array}{c}94 \\
100 \%\end{array}$ \\
\hline
\end{tabular}

TABLE V. DISTRIBUTION RATE OF PATIENT SATISFACTION WITH HEALTH SERVICES IN HOSPITALS DENTAL FACULTY OF DENTISTRY, UNIVERSITY OF HASANUDDIN BASED SERVICE DIMENSION PHYSICAL APPEARANCE.

\begin{tabular}{|c|c|c|c|c|c|c|}
\hline \multirow[b]{2}{*}{ Question Satisfaction } & \multicolumn{5}{|c|}{ Assessment Scores } & \multirow[b]{2}{*}{$\begin{array}{c}\text { n } \\
\%\end{array}$} \\
\hline & $\begin{array}{c}\text { Very } \\
\text { Dissatisfied } \\
n(\%)\end{array}$ & $\begin{array}{c}\text { Not } \\
\text { Satisfied } \\
n(\%)\end{array}$ & $\begin{array}{c}\text { Quite } \\
\text { Satisfied } \\
n(\%)\end{array}$ & $\begin{array}{c}\text { Satisfied } \\
n(\%)\end{array}$ & $\begin{array}{c}\text { Very } \\
\text { Satisfied } \\
n(\%)\end{array}$ & \\
\hline 1). How will doctors & $\begin{array}{c}0 \\
(0.0) \\
\end{array}$ & $\begin{array}{c}0 \\
(0.0) \\
\end{array}$ & $\begin{array}{c}17 \\
(18.1) \\
\end{array}$ & $\begin{array}{c}49 \\
(52.1) \\
\end{array}$ & $\begin{array}{c}28 \\
(29.8) \\
\end{array}$ & $\begin{array}{c}94 \\
100 \% \\
\end{array}$ \\
\hline 2). How Cleanliness doctor's treatment room & $\begin{array}{c}0 \\
(0.0)\end{array}$ & $\begin{array}{c}1 \\
(1.1)\end{array}$ & $\begin{array}{c}25 \\
(26.6) \\
\end{array}$ & $\begin{array}{c}41 \\
(43.6) \\
\end{array}$ & $\begin{array}{c}27 \\
(28.7) \\
\end{array}$ & $\begin{array}{c}94 \\
100 \% \\
\end{array}$ \\
\hline 3). How Cleanliness waiting room & $\begin{array}{c}0 \\
(0.0)\end{array}$ & $\begin{array}{c}3 \\
(3.2)\end{array}$ & $\begin{array}{c}29 \\
(30.9)\end{array}$ & $\begin{array}{c}35 \\
(37.2)\end{array}$ & $\begin{array}{c}27 \\
(28.7)\end{array}$ & $\begin{array}{c}94 \\
100 \% \\
\end{array}$ \\
\hline 4).How cleanliness of equipment to check the patient's teeth & $\begin{array}{c}0 \\
(0.0)\end{array}$ & $\begin{array}{c}5 \\
(5.3)\end{array}$ & $\begin{array}{c}20 \\
(21.3)\end{array}$ & $\begin{array}{c}51 \\
(54.3)\end{array}$ & $\begin{array}{c}18 \\
(19.1)\end{array}$ & $\begin{array}{c}94 \\
100 \%\end{array}$ \\
\hline 5). How completeness of the equipment & $\begin{array}{c}0 \\
(0.0)\end{array}$ & $\begin{array}{c}4 \\
(4.3)\end{array}$ & $\begin{array}{c}43 \\
(45.7)\end{array}$ & $\begin{array}{c}38 \\
(40.4)\end{array}$ & $\begin{array}{c}9 \\
(9.6)\end{array}$ & $\begin{array}{c}94 \\
100 \%\end{array}$ \\
\hline
\end{tabular}

TABLE VI. THE PERCENTAGE DISTRIBUTION OF THE SAMPLE BASED ON THE DIMENSIONS OF THE SATISFACTION LEVEL OF HEALTH SERVICES IN HOSPITALS DENTAL HEALTH FACULTY OF DENTISTRY, UNIVERSITY OF HASANUDDIN.

\begin{tabular}{|c|c|c|c|c|c|c|}
\hline \multirow{2}{*}{ Dimensions of Satisfaction } & \multicolumn{2}{|c|}{ Satisfied } & \multicolumn{2}{|c|}{ Dissatisfied } & \multicolumn{2}{|c|}{ Total } \\
\hline & n & $\%$ & $\mathbf{n}$ & $\%$ & $\mathbf{n}$ & $\%$ \\
\hline Assurance & 65 & 69.1 & 29 & 30.9 & 94 & 100 \\
\hline Emphaty & 68 & 72.3 & 26 & 27.7 & 94 & 100 \\
\hline Responsiveness & 65 & 69.1 & 29 & 30.9 & 94 & 100 \\
\hline Physical appearance & 62 & 66.0 & 32 & 34.0 & 94 & 100 \\
\hline Total & 58 & 61.7 & 36 & 38.3 & 94 & 100 \\
\hline
\end{tabular}




\section{IV.DISCUSSION}

The quality of health services requires two dimensions: technical quality (quality of results) and the functional quality (quality processes). Technical quality focuses on the accuracy of medical diagnoses and procedures while functional quality refers to the way in which the health services provided to patients [6][7].

The main factor that leads to patient satisfaction is an officer, the officer concerned and knowledgeable. In addition to the registration officers and doctors, other officers such as nurses and pharmacy / pharmacist should also provide excellent health services that create patient satisfaction with the quality of service. The patients want a skilled officers and provide them with information. They also want health care providers to work as a collaborative team and communicate with each other effectively to provide good quality services. It will affected not only in business activities but also in health activities. Although many factors can influence the attitudes and desires of the patient, but the patient's perception of service quality the most important role. Aspects of quality of services provided will influence the patient's satisfaction. Patients will compare or ask for a recommendation from another to find the best health care [5][6][11].

Research by Sreenivas [12] shown that better staff and physician relations, interpersonal skills, infrastructure, and availability of eliminated patient's complains have the largest effect in improving patient satisfaction. Thats dimension is increasing the satisfaction of patients treated in hospital and it is affected to the patient's in on Three Urban Hospitals in Guntur District, Andhra Pradesh. The main factor that leads to patient satisfaction is a clinicans, the clinicans concerned and interpersonal skills provide excellent health services that create patient satisfaction with the quality of service. The patients want trained officers and provide them with information they might needed. Therefore, to ensure optimal quality of service, health care providers should be aware of and sensitive to patient satisfaction because it is one factor that can help to improve the outcome of treatment provided [8][11].

The environment of the health service center can indirectly become a parameter in seeing the patient's staisfaction. Research by Tammy[13] shown that Patient satisfaction has been positively influenced by magnet hospitals( hospital on the basis of organizational attributes), even in nonmagnetic hospitals. Study comparing outcomes of inpatient care for AIDS, patient's show statisfied with magnet hopsital and lower moratality than non-magnet hospital approximately 5 per 1000 Medicare discharges, or a $5 \%$ reduction in excess mortality. Environment and being comfort in the room and room service are the key for patients statisfaction [13].

According to study by Chaffin [14] about patients statisfaction in military dental health care clinic. The results of this study clearly indicate that patients are satisfied with the dental care they received at military dental health care clinic. These findings are consistent with previous studies on military gear satisfaction. The result is positive and the majority of patients are very satisfied with the service they received. This is evidenced by the finding that $93.1 \%$ of the respondents were either very or overall satisfied with the service that they received. Similarly, 93.1\% were excellent or overall satisfied with the clinic's ability to handle their dental complaints. Scores for satisfaction with good access, but the number of negative responses indicate this to be a source of discontent for military members.

Research by Orenuga [15] shows high level of satisfaction was related to the communication skills and rapport of staff with the patients. The study is shown same result with a recent study by Table 6 (Percentage distribution of the level of satisfaction of the sample based on the dimensions of dental health services at the dental hospital of Hasanuddin University) at most answered satisfied on the dimensions of empathy as many as $68(72.3 \%)$ samples. So overall the results obtained regarding the level of satisfaction that as many as 58 $(61.7 \%)$ of the sample were satisfied and dissatisfied that as many as $36(38.3 \%)$ of the sample.

Communication is essential established between patient and doctor. Even as a doctor, they also need to speak with the patient. experiments conducted by Asan testing dental provider's opinion when communicating with humans and with computer electronic health records (EHR) in dental care and their effect on dental care provider-patient interaction. The provider survey results indicated that there are different perceptions across provider groups about EHRs and the effect of computer use on communication with patients. Dental assistant's generally shows negative effects on communication with patients owing to computer use. Interview results also indicated that dental care providers may not feel comfortable interacting with the EHR without having any verbal or eye contact with patients during the patient's dental visit [16].

The higher of quality of service given by officer, doctor, nurse or administrator will affect to increase level of statisfaction. Patient satisfaction is a common determinant factor for selecting and using the hospital services or personnel providing services [4][9].

\section{CONCLUSION}

From the research that has been done on the level of patient satisfaction in dental hospital of Hasanuddin University. Based on the four dimensions studied were assurance, empathy, responsiveness, physical appearance, suggests that patients are satisfiedwith the health services in dental hospital of Hasanuddin University. That overall the results obtained regarding the level of satisfaction that as 
many as $58(61.7 \%)$ of the sample were satisfied and dissatisfied that as many as $36(38.3 \%)$ of the sample.

\section{RECOMMENDATION}

Generally on dental and oral health services are expected to maintain and improve the patient satisfaction by considering various dimensions, the dimensions of assurance, responsiveness dimension, the dimension of physical appearance, and dimensions of empathy.

\section{REFERENCES}

[1] K. Edman, A. Holmlund , B. Nordstrom , K. Ohrn. "Attitudes to dental care, Sweden 2003-2013, and clinical correlates of oral healthrelated quality of life." Int J Dent Hygiene, vol.1, 2017.

[2] A. T. Wong, C. Tong, J. W. Wong. "The relationship between Institution Branding, Teaching Quality and Student Satisfaction in Higher Education in Hong Kong." JMHR, vol.4, 2016.

[3] S. R. Habib, S. Ramalingam, A. Al Beladi, A. Al Habib. "Patient's satisfaction with the dental care provided by dental students." J Ayub Med Coll Abbottabad. Vol.26, pp.353$6,2014$.

[4] N. Todua, C. Jashi. "Main Aspects of service quality in the Hotel Industry of Georgia." ICCMI. 2016.

[5] M. Sembel, H. Opod, B. S. Hutagalung. "Gambaran tingkat kepuasan pasien terhadap perawatan gigi dan mulut di puskesmas Bahu". Jurnal e-GiGi, vol.2, .2014.

[6] Akbar. FH, Jaya. MT. " Relationship between Service Quality on Public Health Center and Patient Satisfaction. Global Journal of Health Science. Vol.9, pp.96-102, 2017.
[7] E. E. Ekpe, A. L. Peter. "Sergical patient's satisfaction with services at a tertiary hospital in south-south state of Nigeria." $J M R$, vol.2, pp.157-162, 2016.

[8] P. Naskar, S. Naskar, S. Roy. "Assessment of pastient's satisfaction regarding the service quality of a rural hospital of Burdwan district, West Bengal, India." Int Community Med Publuc Health, vol.3, pp.2222-2228, 2016.

[9] D. Ali. "Patient satisfaction in dental healthcare centers." European Journal of Dentistry, vol. 10, 2016.

[10] P. Zeithmal, L. Berry. "Servqual: multiple-item scale for measuring consumer perceptions of service quality." J Retailing, vol.64, pp.1240, 2008.

[11] G. O. Mainoo, B. Addo, A. G Boadi. "TQM health practices and client satisfaction in a selected health facility in Ghana." IJM, vol.5, pp.47-56, 2014.

[12] T. Sreenivas, N. S. Babu. "A study on patient satisfaction in hospitals (a study on three urban hospitals in guntur district, andhra pradesh)." Int. J. Mgmt Res. \& Bus. Strat, vol.1, pp.113-115, 2012.

[13] L. Tammy, P. Gina, J. Bartley, J. Cox, C. Guither. "Organizational and environmental factors that affect worker health and safety and patient outcomes.” AJIC Journal, vol.30, pp.102-103, 2002.

[14] J. Chaffin, D. Moss, B. Brehm. "Patient Statisfaction in US army dental treatment facilities." Army Medical Department Journal, 2005.

[15] O. O. Orenuga, O. O. Sofola, O. O. Uti. "Patient satisfaction: a survey of dental outpatients at the Lagos University Teaching Hospital, Nigeria." Nig Q J Hosp Med, vol.19, pp.47-52, 2009.

[16] O. Asan, Z. Ye, A. Acharya. "Dental care providers' and patients' perceptions of the effect of health information technology in the dental care setting." vol.144, pp.1022-1023. 